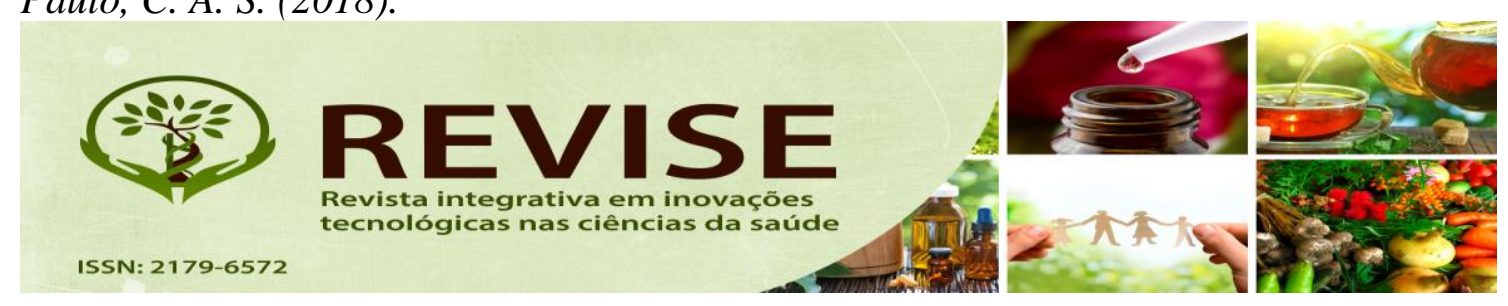

\title{
Conferência: POLÍTICAS TRADICIONAIS NO CONTEXTO DA CONTEMPORANEIDADE
}

Carlos Alberto Santos de Paulo

$C C S-U F R B$

\section{RESUMO}

O artigo registra as conferências do evento Congresso internacional de inovação tecnológica nas ciências da saúde: a sustentabilidade das práticas integrativas à agroecologia, mais especificamente a conferência Políticas tradicionais no contexto da contemporaneidade. Com o foco na medicina indígena e afrodescendente a conferência abordou no contexto da contemporaneidade, o adiamento da construção de uma sociedade igualitária pela naturalização da história de violência com o advento da escravidão e dos saberes científicos coloniais. O evento aconteceu de 15 a 18 de novembro de 2017 no IFBA SAJ sob a direção da Universidade Federal do Recôncavo da Bahia.

Palavras-chave: PICS. Medicina indígena. Medicina africana. Saúde. Movimento.

\begin{abstract}
The article registers the conferences of the event International Congress of Technological Innovation in Health Sciences: the sustainability of integrative practices in agroecology, more specifically the conference Traditional Policies in the context of contemporary times. Focusing on indigenous and African descent medicine, the conference addressed in the context of contemporary times, the postponement of the construction of an egalitarian society by the naturalization of the history of violence with the advent of slavery and colonial scientific knowledge. The event took place from November 15 to 18, 2017 at IFBA SAJ under the direction of the Federal University of Recôncavo da Bahia.

Keywords: PICS. Indigenous medicine. African medicine Health. Movement.
\end{abstract}




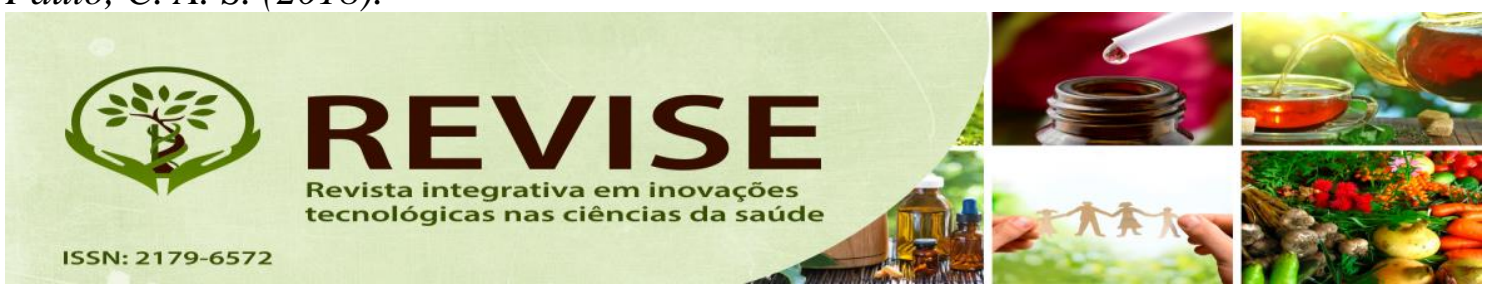

Tomamos como ponto de partida, a perspectiva do encontro colonial, cujos pilares estabeleceram a base da dominação europeia. As presenças indígena e negra, na conformação da nação brasileira, sedimentaram as raízes sobre as quais, até o presente momento, estão sustentadas as relações assimétricas na sociedade brasileira.

Ao abordar as políticas tradicionais no contexto da contemporaneidade, é fundamental avaliar em que medida as pretensões de construção de uma sociedade igualitária foram adiadas pela naturalização da história de violência com o advento da escravidão e dos saberes científicos coloniais.

Desta forma, levantamos algumas questões balizadoras:

1. O longo período decorrido de uma economia baseada no modo de produção escravista permitiu a sedimentação de um modelo de sociedade na qual indígenas e negros foram efetivamente integrados a um projeto de nação? Ou houve uma gradativa incorporação de alguns aspectos culturais os quais ocupam um lugar ilustrativo de uma pretensa configuração democrática na contemporaneidade?

2. De que forma as lutas políticas dessas comunidades passaram a ocupar um lugar central nas preocupações da nação brasileira? Importante ressaltar que não se trata de pequenas comunidades, mas de numerosos povos (indígenas) e milhares de comunidades tradicionais de matriz africana.

3. Em que medida, o Estado Brasileiro admitiu essas questões enquanto uma questão nacional a requerer respostas para além da formalidade jurídico/procedimental?

Nossa hipótese para o debate é a de que, na contemporaneidade, a questão racial, ainda carece de um lugar destacado na conformação de um processo democrático aberto. Há desafios profundos a serem enfrentados, sobretudo quando pensamos em uma economia de mercado global que reduz a democracia liberal a um caráter formal, negando o acirramento das contradições e as novas dimensões dos conflitos sociais. $\mathrm{O}$ racismo, sobretudo o modelo adotado no país, ainda se mantém vigoroso e mimético e suas ressignificações. 